\title{
PARTICIPATORY GOVERNABILITY UNDER DEVELOPMENT: THE INSTITUTION OF CITIZEN PARTICIPATION AS THE BASIS FOR THE DESIGN OF THE "GOVERNMENT AS A PLATFORM" IN DEVELOPING COUNTRIES
}

\author{
Kirill Neverov \\ Saint Petersburg State University, 7-9 Universitetskaya Emb., St Petersburg 199034, Russia
}

\begin{abstract}
An important point of the government as a platform is coordination with actors traditionally external for public administration (citizens, business) through shared software, data, and collaborative services. Unlike e-government, the focus in digital government is shifting to citizen participation: digital government focuses on services, functions and governance through citizen involvement. The key point here is the interaction of man and technology: the implementation design is a set of principles, methods and norms of interaction between man and technology, that is, a techno-ecological system. The main thesis of the study is the following proposition: the institution of participation is the basis of the design of the "government as a platform" due to the deep foundations of Web 3.0 technology, which encourage participation and have a collaborative nature. Participatory governance is inherent in digital governance. In our study, we strive to demonstrate how the factors determining the classification of countries as developing affect the participatory governability, implemented through the government as a platform. In this study, we adhere to the Lean Government approach.
\end{abstract}

\section{KEYWORDS}

Participatory Governability, Digital Government, Latin America

\section{INTRODUCTION}

The digitalization of public administration is not so much reduced to literally introducing modern information and communication technologies (ICT) and new digital technologies (Internet of Things, Big Data analysis, AI, etc.) into the practical activities of executive bodies. The key point here is the interaction of man and technology: the implementation design is a set of principles, methods and norms of interaction between man and technology, that is, a techno-ecological system.

The key characteristic of the introduction of digital government on the basis of the concept of "government as a platform" is political design. The design of implementing digital government can be considered as an essential characteristic of public administration, determining the interrelation of processes and technologies of control from below to control from above (thus, the design is determined by the interrelation of control technologies from above and below). The implementation design also implies the principles embodied in digitalization and implemented through the "government as a platform": ethical principles (openness, citizen awareness, understandability for citizens), values, interaction with citizens, their participation, etc.

The main thesis of the study is the following proposition: the institution of participation is the basis of the design of the "government as a platform" due to the deep foundations of Web 2.0 technology, which encourage institution of participation and have a collaborative nature. Therefore, participatory governance is inherent in digital governance. 
The term governability in our study is revealed in the context of the concept of a "coordinating state", suggested in previous study (Smorgunov et al. 2019), the main idea of which is that the authorities in the new conditions, although they retain a central role in the processes of policy development and implementation, but increasingly perform the function of coordinating network interactions.

If we refer to the technological side of the implementation of government as a platform, then the basis here is such technologies and concepts as artificial intelligence, blockchain and distributed ledger technology, smart contracts. Internet of Things and Big Data analysis are also on the agenda (Ovanessoff A., Plastino E. 2017) (Webfoundation.org 2020. ) (MIT Technology Review Insights 2020) (Rodríguez P. et al 2017.) (Ordoñez L.A.T. et al. 2019.) (Moura, Ph., Nicoletti, S. 2018.)

Under terms "developing state" or "developing country" we mean a country with a less developed industrial base (industries) and a low Human Development Index (HDI) relative to other countries (O'Sullivan, Sheffrin, 2003). It is assumed that the problems that states need to solve will also determine the design of implementation and the nature of citizen participation, as well as the forms in which they are clothed.

\section{GOVERNMENT AS A PLATFORM (GAAP)}

The concept of a government as a platform (GaaP) is based on the deep foundations of Web 2.0 and Web 3.0 technology of a collaborative nature, which are reflected in Gov.2.0 and Gov.3.0 (O'Reilly, T. 2010).

Therefore, from a public value perspective, the key challenge of the GaaP is to enable, control, and govern the dynamic combination of the needed resources, routines, and structures to adapt and respond to emerging and unpredictable citizens' needs, so that all the different values and expectations are simultaneously and dynamically fulfilled (Cordella, A., Paletti, A. 2019).

Platforms can be seen as a kind of regulated environment, allowing developers, users and others to interact with each other, to distribute data, services and applications, allowing governments to more easily monitor what is happening and promote innovation in public policy (except other areas). Since the platforms are not isolated, their integration with each other and other systems, ensuring their interoperability is a problem, since everything is connected to everything in the network (Janssen, M., Estevez, E. 2013).

The network approach leads to cooperation in the governance process, while its adoption depends on the willingness of government departments. Networks of actors foster participation, which affects regional development, forming a community. The platform acts as a playground for public participation and collaboration. The participation of citizens in the governance process, their involvement affects the perception of citizens by the government, and the modules of the government as a platform allow citizens to feel part of the process from which they were removed in the traditional offline format of public administration (Verma, R. K. et al 2017).

For the approach of "lean government" (1-Government), which is the philosophy of a minimal state, inherent the reduction of the administrative burden and the focus on efficiency while pursuing enhanced services and innovation, and orchestrating networks which are enabled by platforms. The general idea of l-Government is that platforms play a key role in connecting developers, content providers, government agencies, and service providers and users (Janssen, M., Estevez, E. 2013).

Digitalization implies the emergence of a new form of governability, which is essentially a network effect, which is the result of an increasing number of participants in network (Smorgunov, L. 2019. Participatory...). Openness improves efficiency in terms of increasing new participating projects. The network effect works here: the more participants, the higher the network efficiency at lower costs for individual participants. Promoting innovation is also an essential feature of platform openness (O'Reilly, T. 2010). For governments, integration with other platforms is necessary because users tend to use multiple platforms, and the added value of the platform can be enhanced by offering a seamless interconnection between the platforms (Janssen, M., Estevez, E. 2013).

Digital governability combines two multidirectional movements: control from above (from the state) and control from below (horizontal level of control, control of citizens by citizens / civil control). Control from above means "the ability of large organizational systems (states, TNCs, etc.) based on processing large amounts of data about citizens not only to control, but to use in the directions necessary for these systems, that is, to control the behavior of large masses of people (through disclosing of human space) (Smorgunov L. 
2019. Institutionalization of...). Control from below is manifested through "increased governability through self-observation, social control and self-censorship. The essence of governability here is programming human behavior through network identification as an accessory (Smorgunov L. 2019. Institutionalization of...).

\section{INSTITUTION OF PARTICIPATORY GOVERNABILITY IN DEVELOPING STATES}

The following cases were selected for the study: Argentina, Bolivia, Brazil, Uruguay. These countries are included in the list of developing countries according to the UN version (United Nations Homepage 2020. The World Economic...). Two of them relate to fuel-exporting countries - Bolivia and Ecuador [25, p.167]. The programs of digital development of countries, the platform of digital government were analyzed. The following digitalization programs are analogues of EU's ISA2 programs. However, their negative side is a lack of technological details - these programs are more for policy-makers, than for engineers. Technical documentation is not available in free access.

The choice of cases was determined by development indicators (human development index, GDP) and the level of digitalization of public administration. HDI rankings are: Bolivia - 114, Brazil - 79, Uruguay - 57 (United Nations Homepage 2020. 2019 Human Development...) Ranking by estimated GDP in 2020: Bolivia - 88, Brazil - 8, Uruguay - 94 (International Monetary Fund 2020). Ranking in UN EGDI: Bolivia - 97, Brazil - 54, Uruguay - 26 (United Nations Homepage 2020. UN E-Government...). Ranking in UN E-Participation Index: Bolivia - 90, Brazil - 18, Uruguay - 29 (United Nations Homepage 2020. UN E-Government...).

The key guiding document for Argentina's digital government efforts is its Digital Agenda 2030, which was formally implemented in December 2018 after a development process secured through the participation and support of all relevant ministries. It provides a government-wide project and principles-based vision for the digital transformation of the public sector. The Digital Agenda is an important umbrella policy document and represents a significant step forward in establishing a common vision and goals. It moves Argentina closer to meeting the OECD Recommendation of the Council on Digital Government Strategies; however, it does not constitute a full digital government strategy in itself. The permanent adoption of digital technologies should accelerate the transformation of the Government, allowing the construction of a modern, efficient, transparent, close to the citizen, simple, trustworthy and participative State» (Gob.ar 2020), as well as subsection 2 "Government and open data": «Promote a collaborative and participative government. Create instances of dialogue between the Government and society. Promote innovation in the public sector through initiatives for the co-creation of public policies between citizens, the State and the rest of the nations (Gob.ar 2020).

The key guiding document for Bolivia's digital government is its Plan de Implementación de Gobierno Electrónico 2017 - 2025 (Plan of Implementation of Digital Government 2017 - 2025). In the section "Open Government of Participation" the following strategy is spelled out: "Deepening, through the use of Electronic Government tools, the processes of participatory governability and social control of citizens on issues of interest, generating greater interaction of dialogue between the population and the State. Institution of participation and social control are two fundamental pillars of the way in which State policy is built and directed. In this sense, ICTs can help to deepen the full exercise of the right to participation and social control individually and collectively. The spectrum of citizen participation will be expanded with the use of electronic government tools and digital media, through which the State will collect and interact around the requirements and proposals of citizens" (Gob.bo 2020).

Brazil implements the Brazilian digital transformation strategy and the Effective Brazil strategy. In particular, the following steps are spelled out in them: implementation of the Government Open Data Policy, in cooperation with other governmental bodies, aiming to consolidate a culture of transparency, social participation, accountability, research, innovation and entrepreneurship, through the use of free, reliable public data in open formats, made available in the Open Data Portal; expanding social participation on public services and policy life cycles; existence of a social participation digital platform as a locus of excellence for dialogue between government and civil society. Its objective ought to be the promotion of public interaction, publication of policy-related content, and access to online communication and debate tools; to consolidate the Digital Government Platforms: Data Analysis Platform, Data and System Interoperability Platform, 
Transparency Portal, Government Open Data Platform, and the Digital Citizen Participation Platform; to maintain and improve a digital social participation platform as a place of excellence for dialogue between government and civil society (Gov.br 2020).

The key documents for digital transformation in Uruguay are Agenda Digital 2020 (Digital Agenda 2020) and Plan de Gobierno Digital 2020: Transformación con equidad (Plan of Digital Government 2020: Transformation with justice). In terms of participation, documents contain the following information: encourage different ways of approaching the relationship between citizens and the State, promoting transparency, accountability, citizen participation and the development of better services, generating direct contact channels with people and improving the quality of care in the services provided; deepen the open government culture, implementing e-participation mechanisms at $100 \%$ of central government agencies and increasing by $100 \%$ the offer of open government data; build secure environments and trust-based forms of interaction, in order to promote full participation in the information society; articulate multi-stakeholder actions and enhance their cooperation through a National Cybersecurity Operations Centre (SOC Nac) through public-private participation (Uruguaydigital.uy 2020.).

ICT perspectives in Latin America are huge due to level of urbanization (in 2019 80,87\% of the total population of Latin America \& Caribbean lived in urban areas and cities (Statista 2020)) and Internet coverage (almost $70 \%$ of Latin America's population have access to the Internet, which is $58,8 \%$ of world Internet users [9]). However, despite of potential, brain drain and lack of qualified human resources in ICT is still a problem for Latin American digitalization programs (Insead.edu 2020).

\section{CONCLUSION}

Thus, we can conclude that the developing countries of Latin America are inclined to carry out a digital transformation and form a government as a platform based on a design that involves participatory governability. The collaborative components that are embedded in the nature of digital technologies, which make it possible and stimulate the participation of citizens in the production of public services, in the case of developing countries make it possible to involve in the public policy the categories of citizens who were previously out of state attention (Bottom of the Pyramid) and increase the state's stinginess in the eyes of citizens through the formation of a positive algorithm of political behavior due to the active involvement of citizens in the field of political decisions that are of public importance and reflect public interest. The government as a platform, being in itself a social value, allows you to create a new social value through involving citizens, civil society, public institutions, non-commercial institutions and business representatives in the interaction. The factors relating the states to developing ones can be considered in two ways: on the one hand, they are an obstacle to the transformation of state administration into a digital government due to the obvious high cost of such undertakings; on the other hand, the restructuring of the traditional hierarchical vertical centralized state platform format will reduce corruption by minimizing public administration, more efficiently redistribute available funds in accordance with the request of citizens, modify policies faster and with accuracy. Participatory governance is changing not only the public administration system, but also the political thinking of society.

\section{ACKNOWLEDGEMENT}

The author disclosed receipt of the following financial support for the research, authorship, and/or publication of this article: This work was supported with a grant from the Russian Science Foundation (grant 19-18-00210 "Political ontology of digitalization: Study of institutional bases for digital forms of governability").

\section{REFERENCES}

Cordella, A. and Paletti, A., 2019. Government as a platform, orchestration, and public value creation: The Italian case. In Government Information Quarterly, Vol. 36, №4, pp. 1-15;

$\begin{array}{ccccccc}\text { Gob.ar, } 2020 . & \text { Agenda } & \text { Digital Argentina } & \text { 2030. } & \text { [online] Available } \\ \text { http://servicios.infoleg.gob.ar/infolegInternet/anexos/315000-319999/318677/res138.pdf [Accessed 15 June, 2020]; }\end{array}$ 
Gob.bo, 2020. Plan de Implementación de Gobierno Electrónico 2017 - 2025. [online] Available at: https://agetic.gob.bo/2-plan-de-implementacion-de-gobierno-electronico.pdf [Accessed 15 June, 2020];

Gov.br, 2020. Brazilian digital transformation strategy. [online] Available at: http://www.mctic.gov.br/mctic/export/sites/institucional/sessaoPublica/arquivos/digitalstrategy.pdf\#: :text=The $\% 20$ role $\% 20$ of $\% 20$ the $\% 20$ Brazilian,prosperous $\% 2 \mathrm{C} \% 20$ free $\% 20$ and $\% 20$ fair $\% 20$ society [Accessed 15 June, 2020];

Insead.edu, 2020. The Global Talent Competitiveness Index 2020. [online] Insead.edu. Available at: https://www.insead.edu/sites/default/files/assets/dept/globalindices/docs/GTCI-2020-report.pdfp.42 [Accessed 13 Sept, 2020];

International Monetary Fund, 2020. World Economic Outlook Database, October 2020. [online] IMF.org. Available at: https://www.imf.org/en/Publications/WEO/weo-database/2020/October_Accessed 01 Nov, 2020];

Janssen, M. and Estevez, E., 2013. Lean government and platform-based governance-doing more with less. In Government Information Quarterly, Vol.30 (SUPPL. 1), S1-S8;

MIT Technology Review Insights, 2020. The global AI agenda: Latin America. [online] MIT Technology Review Insights. Available at: https://mittrinsights.s3.amazonaws.com/AIagenda2020/LatAmAIagenda.pdf [Accessed 10 Sept, 2020];

Moura, Ph. and Nicoletti, S., 2018. Making smart cities and IoT a reality in Latin America: a quick guide for decisionmakers. [online] Gsma.com. Available at: content/uploads/2018/11/IoTGuide-ENG.pdf [Accessed $10 \mathrm{Sept}, 2020$ ];

O'Reilly, T., 2010. Government as a Platform. [online] MIT Press Journals. Available at: https://www.mitpressjournals.org/doi/pdf/10.1162/INOV_a_00056\#: :text=Government\%20information\%20and\%20 services\%20can,an\%20improved\%20approach\%20to\%20governance [Accessed 15 June, 2020];

Ordoñez L.A.T. et al., 2019. Approach to Blockchain and Smart Contract in Latin America: Application in Colombia. In Communications in Computer and Information Science, Vol.1052, pp. 500 - 510;

O'Sullivan, A. and Sheffrin, S.M., 2003. Economics: Principles in Action. Upper Saddle River, New Jersey;

Ovanessoff A. and Plastino E., 2017. How Artificial Intelligence Can Drive South America's Growth. [online] Accenture.com. Available at: https://www.accenture.com/_acnmedia/pdf-49/accenture-how-artificial-intelligencecan-drive-south-americas-growth.pdf [Accessed 10 Sept, 2020];

Rodríguez P. et al, 2017. Using Big Data and its Analytical Techniques for Public Policy Design and Implementation in Latin America and the Caribbean. [online] Inter-American Development Bank. Available at: https://publications.iadb.org/en/using-big-data-and-its-analytical-techniques-public-policy-design-andimplementation-latin-america [Accessed 10 Sept, 2020];

Smorgunov L., 2019. Institutionalization of Governability and the Problem of Veillance in the Space of Digital Communications. In South-Russian Journal of Social Sciences, Vol. 20, №3, pp. 62-75;

Smorgunov L.et al., 2019. Evolution of the Concept of Governability in the Context of Dizitalization. Proceedings of the International Conference ICT, Society and Human Beings 2019, Smart Cities 2019 and Web Based Communities and Social Media 2019. Porto, Portugal, p. 281-285;

Smorgunov, L., 2019. Participatory governability under digitalization conditions: network ef-fect and institutions. In The Caspian region: Politics, Economics, Culture, Vol. 4, № 61, pp. 43-49;

Statista, 2020. [online] Available at: https://www.statista.com/statistics/699089/urbanization-in-latin-america-andcaribbean [Accessed 13 Sept, 2020];

United Nations Homepage, 2020. 2019 Human Development Index Ranking. [online] United Nations. Available at: http://hdr.undp.org/en/content/2019-human-development-index-ranking_[Accessed 01 Nov, 2020];

United Nations Homepage, 2020. The World Economic Situation and Prospects 2020. [online] United Nations. Available at: https://www.un.org/development/desa/dpad/wp-content/uploads/sites/45/WESP2020_FullReport.pdf [Accessed 15 June, 2020];

United Nations Homepage, 2020. UN E-Government Knowledgebase. [online] United Nations. Available at: https://publicadministration.un.org/egovkb/en-us/Data-Center [Accessed 01 Nov, 2020];

Uruguaydigital.uy, 2020. Plan de Gobierno Digital 2020: Transformación con equidad. [online] Available at: https://uruguaydigital.uy/wps/wcm/connect/urudigital/ff2fba97-7871-474e-85ec-

a43a75ef3376/Descargar+Agenda+Digital+2020++original.pdf?MOD=AJPERES\&CONVERT_TO=url\&CACHEID=ff2fba97-7871-474e-85ec-a43a75ef3376, ast accessed 2020/06/15 [Accessed 15 June, 2020];

Verma, R. K. et al, 2017. Government portals, social media platforms and citizen engagement in India: some insights. In Procedia Computer Science, Vol. 122, pp.842-849;

Webfoundation.org, 2020. How Are Governments In Latin America Using Artificial Intelligence? A proposal for effective and legitimate implementations of AI systems in the public sector. [online] Available at: http://webfoundation.org/docs/2018/07/AI-in-Latin-America_Overview.pdf [Accessed 10 Sept, 2020]. 